\title{
Exploring entrepreneurial pivoting and the factors that trigger pivots by tech startups
}

\author{
Pavan Kumar Sala ${ }^{1}$, Simon P. Philbin ${ }^{1}$, Safia Barikzai ${ }^{1,2}$ \\ ${ }^{I}$ Nathu Puri Institute for Engineering and Enterprise, School of Engineering \\ ${ }^{2}$ Computer Science and Informatics, School of Engineering \\ London South Bank Univeristy \\ London, United Kingdom \\ Email: salap@1sbu.ac.uk,philbins@1sbu.ac.uk, safia.barikzai@1sbu.ac.uk
}

\begin{abstract}
Technology entrepreneurship is an emerging domain in the field of entrepreneurship and the practice-oriented method called the Lean Startup approach (LSA) has made a big impact in this area. However, many technology startups continue to have survivability issues. This study focuses on understanding the theory of entrepreneurial pivoting and its associated factors. In this study, we have collected secondary data comprising 80 tech startups to validate the different types of pivots they pursued by the companies and the factors that triggered the pivoting. The most common pivots among these were found to be customer segment pivot and customer need pivot.
\end{abstract}

Keywords-Lean Startup approach; pivots and factors; technology entrepreneurship.

\section{INTRODUCTION}

The Lean Startup approach (LSA) is considered as one of the most popular practitioner-oriented approaches in the entrepreneurship literature. This approach describes various aspects including validated learning or customer development, minimum viable product (MVP), market opportunity navigation, perseverance and pivoting. Blank (2013), Ries (2011), and Osterwalder \& Pigneur (2010) are considered as critical contributors to the LSA concept as their books on the subject have been sold in the millions and the practices adopted by countless entrepreneurs. However, in the field of entrepreneurship there remains a gap between academic research and practitioners. On the one hand, practitioners do not necessarily pay much attention to research studies and on the other hand, there is a need for research to fully characterise the entrepreneurial process [1].

Technology advancement is considered a critical aspect of economic growth as industries develop through innovating, exploiting and commercialising emerging technologies. Entrepreneurship has many domains, and one such domain is technology entrepreneurship (TE), which is defined as assembling resources, technical systems and the strategies by an entrepreneur to pursue opportunities [2]. TE has also been described in terms of digital entrepreneurship [3].
This exploratory research study focuses on understanding the concept of technology entrepreneurship in the context of the Lean Startup approach and entrepreneurial pivoting by startups. The study seeks to validate the type of pivots pursued by tech startups and the factors that trigger pivots.

\section{LITERATURE REVIEW}

\section{A. Technology entrepreneurship}

The universal definition of entrepreneurship is the "creation of new enterprise" [4]. It can also be explained as the process of extracting revenue from new and distinctive amalgamations of resources in an uncertain environment. Entrepreneurship is considered as a positive force that contributes to the growth of both developed and developing economies. Furthermore, entrepreneurship has played a significant role in exploiting technological innovations [3]. It can be observed that researchers in the field of entrepreneurship seek to address questions such as the following: How do entrepreneurs create value propositions? Why do some startups fail to become sustainable in the long run? How does an entrepreneur decide whether or not to persevere or pivot? [5], [6]. Entrepreneurship has sub-branches and arguably technology entrepreneurship is one of the essential fields. Indeed, Spiegel and Marxt [2] defined "Formation" and "Exploitation" as crucial phases of TE. The first phase is formation, which involves the recognition of opportunities. Exploitation is the second phase where strategies are developed to exploit the recognised opportunities. TE has a third phase known as "Renewal". Moreover, Eliakis et al. [3] defined technology entrepreneurship as developing innovative digital technologies or using such technologies by forming new startups and transforming existing businesses.

Technology entrepreneurship does not necessarily mean just adopting digital technologies by technology startups; it acts as an interface between innovation and entrepreneurship. Innovation can be defined as a degree of newness by generating ideas, processes, products, or services that enable a technology 
breakthrough. Furthermore, entrepreneurship is inferred as exploring and exploiting business opportunities to create a value proposition. The domain of TE can be characterised through the following: a) science and technology policies; b) exploration and fostering of new technologies across various industries; c) government support to science and technology to stimulate new technologies; and d) market regulations that govern the entrepreneurial initiatives [7]. Technology entrepreneurship has gained both academic and policymakers' interest over the last two decades. Leading entrepreneurs such as those that founded major tech companies in the Silicon Valley area in California (USA) were able to succeed due to identifying and evaluating opportunities to create value propositions enabled through emerging technologies. However, researchers like Sobel and Clark [8] argue that even though TE is widely recognised, it still lacks a unified framework [9]. Furthermore, TE has evolved further and broadened through assimilation and evolution of new topics in the literature on entrepreneurship. One such new topic is product or service development based on customer feedback, which has been considered as the need to "probe and learn the process" [10].

\section{B. Entrepreneurial pivoting}

During the inception and launch phases, a tech startup undergoes frequent changes in the business model and the value-capturing technique due to resource scarcity and external market conditions. In this regard, startup companies can adopt the Lean Startup approach. The global manufacturing industry adopted the principles of lean philosophy over the last several decades. The five principles of lean are as follows: a) creating value to the customers; b) identifying the value stream; c) creating a process flow to prevent breakdowns, re-entrant loops, low-quality products or services; d) producing high-quality products that are efficient and valuable for the customers; e) identifying and eliminating excess engineering hours in order to be cost-effective [11].

Startups are defined as a group of talented people trying to seize an opportunity by turning an idea into a product [12]. An entrepreneur may encounter a question, i.e., whether to persevere or pivot while commercializing their idea to develop a competitive product or service. Eric Ries author of The Lean Startup and an entrepreneur defined the pivot as a "structural course of correction designed to test a new fundamental hypothesis" [13]. He says entrepreneurs should pivot from time to time to learn the customers' needs, problems, and preferences to develop a market-fit product or service [14]. The LSA model emphasises experimental entrepreneurship to explore opportunities, which can be viewed as an active search and iterative design solution. In such a case, companies such as GE, Motorola, Searle and Corning are some of the examples that have followed the probe and learn process [15]. For any organization, continuous innovation will help develop new ideas, products, and organizational structure to support longterm goals. Those strategies help to further build the success of companies. It has been reported that Facebook and Twitter are two classic examples of pivoting [13].

A total of fourteen pivots have been identified from the literature $[12,13,16]$ that are further categorized into four levels, which are as follows: Product level pivots are those that lead to a change in the products/services offered by the company (1). Market level pivots focus on customers and the market in which a company operates (2). Strategy level pivots focus on the way to generate more value for the company (3). People level pivots are associated with resources in a startup (4). Table I illustrates all the pivots categorized under the above four levels.

TABLE I. TyPes OF Pivots. SOURCE: [12, 13, 16]

\begin{tabular}{|c|c|c|c|}
\hline S. No & Level & Name of pivot & Source \\
\hline \multirow[t]{4}{*}{$\bar{I}$} & \multirow{4}{*}{$\begin{array}{l}\text { Product } \\
\text { level pivot }\end{array}$} & Zoom-in pivot & \multirow{4}{*}{ Ries [13] } \\
\hline & & Zoom-out pivot & \\
\hline & & Technology pivot & \\
\hline & & Platform pivot & \\
\hline \multirow[t]{4}{*}{ II } & \multirow{4}{*}{$\begin{array}{l}\text { Market level } \\
\text { pivot }\end{array}$} & Customer segment pivot & \multirow[t]{3}{*}{ Ries [13] } \\
\hline & & Customer need pivot & \\
\hline & & Channel pivot & \\
\hline & & Market segment pivot ${ }^{\mathrm{a}}$ & Bajwa [16] \\
\hline \multirow[t]{5}{*}{ III } & \multirow{5}{*}{$\begin{array}{l}\text { Strategy } \\
\text { level pivot }\end{array}$} & Value capture pivot & \multirow[t]{3}{*}{ Ries [13] } \\
\hline & & $\begin{array}{l}\text { Business architecture } \\
\text { pivot }\end{array}$ & \\
\hline & & Engine of growth pivot & \\
\hline & & Complete pivot & Bajwa [16] \\
\hline & & Side project pivot & Bajwa [16] \\
\hline IV & $\begin{array}{l}\text { People level } \\
\text { pivot }\end{array}$ & Social pivot & Hirvikoski [12] \\
\hline
\end{tabular}

a. Name changed from zoom-in pivot to market segment pivot

The market segment pivot (name changed from zoom-in pivot to avoid confusion), complete pivot and side-project pivot were identified by Bajwa [16]. The social pivot was identified by Hirvikoski [12], and the remaining ten pivots were identified by Ries [13]. Furthermore, Bajwa [16] identified eleven factors may trigger a startup to change its direction (pivot). Table 2 illustrates all of these factors.

TABLE II. FACTORS THAT TRIGGER PIVOTS. SOURCE: [16]

\begin{tabular}{|l|l|}
\hline \multicolumn{1}{|c|}{ S. No } & \multicolumn{1}{c|}{ Factors } \\
\hline I & Customer feedback (positive and negative feedback) \\
\hline II & Technology challenges \\
\hline III & Competition \\
\hline IV & Unscalable business \\
\hline V & Wrong timing \\
\hline VI & Market conditions \\
\hline VII & Influence of investor, partner or founder \\
\hline VIII & Legal issues \\
\hline
\end{tabular}




\begin{tabular}{|l|l|}
\hline S. No & \multicolumn{2}{|c|}{ Factors } \\
\hline IX & Flawed business model \\
\hline X & Side project success \\
\hline XI & Business financials \\
\hline
\end{tabular}

\section{RESEARCH APPROACH}

The objective for this research study is to validate the type of pivots pursued by startup companies and the factors that trigger such pivots. In order to address this objective, we collected secondary data from various academic journals and company websites. Secondary data is a dataset that a researcher does not collect by him/herself but instead analyses existing data [17]. The benefits of using secondary data are eliminating financial and logistical obstacles while collecting primary data [18]. However, certain precautions must be taken. A researcher should elucidate the limitations using secondary data and explain the actions taken to use the original data set for the new research gap. The secondary data should be conscientiously interpreted to generate a hypothesis and not to prove hypothesis [17], [18].

As part of the secondary data collection, we reviewed academic articles $[16,19,20]$ that discuss different types of pivots and possible factors behind pursuing those pivots. At the same time, we have searched the internet to identify technology startups/companies that have pivoted. Examples of the search keywords used in the internet search are as follows: "business pivots", "pivots by startups", "famous business pivots" and "pivots". While looking for data, we focussed only on tech startup companies to understand what type of pivots they have pursued. The intention behind collecting the secondary data is to understand what type of pivots have been pursued by technology startup companies. The secondary data was collected from multiple sources (academic articles and different websites), out of which $60 \%$ was collected from Bajwa et al., [14], 30\% was from the internet (different websites searched in google) and the remaining 10\% was from Comberg et al. [19], Terho et al. [20] and Hirvikoski [12]. We collected data of startup companies from across the globe and this includes startups from Canada, Finland, France, Germany, India, Ireland, Israel, Japan, Mexico, Republic of Tunisia, Spain, UK and USA.

The secondary data study shows what type of pivots pursued by tech startups/companies and how successful they are after pivoting. Tech companies such as Twitter and Facebook are international examples that pivoted at a very early stage of their journey [12]. During data collection, we came across websites that illustrated the startup companies that pivoted to face pandemic situation caused due by COVID-19. We studied the types of pivots those tech startups pursed and labelled their factor as market condition (due to pandemic).

Table III provides the details of companies that pursued pivots and the factors that trigger pivots. We have anonymized the company names.
TABLE III. COMPANIES WITH PIVOTS THEY PURSUED AND FACTORS ASSOCIATED WITH THOSE PIVOTS. SOURCES: [12, 16, 19-34]

\begin{tabular}{|c|c|c|}
\hline Company & Factor (s) & Pivot (s) \\
\hline Company-1 & $\begin{array}{l}\text { Influence of investor, } \\
\text { partner or founder }\end{array}$ & Platform pivot \\
\hline Company-2 & $\begin{array}{l}\text { Customer feedback } \\
\text { (positive) }\end{array}$ & Platform pivot \\
\hline Company-3 & $\begin{array}{l}\text { Market conditions } \\
\text { (due to pandemic) }\end{array}$ & Platform pivot \\
\hline Company-4 & $\begin{array}{l}\text { Market conditions } \\
\text { (due to pandemic) }\end{array}$ & Value capture pivot \\
\hline Company-5 & $\begin{array}{l}\text { Customer feedback } \\
\text { (negative) }\end{array}$ & Zoom-in pivot \\
\hline Company-6 & Unscalable business & Customer need pivot \\
\hline Company-7 & Flawed business model & Zoom-out pivot \\
\hline Company-8 & $\begin{array}{l}\text { Influence of investor, } \\
\text { partner or founder, flawed } \\
\text { business model, market } \\
\text { conditions, business } \\
\text { financials and technology } \\
\text { challenges }\end{array}$ & $\begin{array}{l}\text { Customer segment } \\
\text { pivot, business } \\
\text { architecture pivot, } \\
\text { value capture pivot } \\
\text { and engine of growth } \\
\text { pivot }\end{array}$ \\
\hline Company-9 & $\begin{array}{l}\text { Customer feedback } \\
\text { (negative) }\end{array}$ & Customer need pivot \\
\hline Company-10 & Unscalable business & Customer need pivot \\
\hline Company-11 & Legal issue & Complete pivot \\
\hline Company-12 & $\begin{array}{l}\text { Wrong timing and } \\
\text { unscalable business }\end{array}$ & Customer need pivot \\
\hline Company-13 & Flawed business model & $\begin{array}{l}\text { Customer segment } \\
\text { pivot }\end{array}$ \\
\hline Company-14 & $\begin{array}{l}\text { Influence of investor, } \\
\text { partner or founder, flawed } \\
\text { business model, market } \\
\text { conditions, business } \\
\text { financials and technology } \\
\text { challenges }\end{array}$ & $\begin{array}{l}\text { Customer segment } \\
\text { pivot, channel pivot, } \\
\text { engine of growth pivot } \\
\text { and value capture } \\
\text { pivot }\end{array}$ \\
\hline Company-15 & Unscalable business & Zoom-out pivot \\
\hline Company-16 & $\begin{array}{l}\text { Market conditions } \\
\text { (due to pandemic) }\end{array}$ & Value capture pivot \\
\hline Company-17 & $\begin{array}{l}\text { Market conditions } \\
\text { (due to pandemic) }\end{array}$ & Complete pivot \\
\hline Company-18 & $\begin{array}{l}\text { Customer feedback } \\
\text { (negative) and flawed } \\
\text { business model }\end{array}$ & Complete pivot \\
\hline Company-19 & $\begin{array}{l}\text { Customer feedback } \\
\text { (positive) }\end{array}$ & $\begin{array}{l}\text { Customer segment } \\
\text { pivot }\end{array}$ \\
\hline Company-20 & $\begin{array}{l}\text { Market conditions } \\
\text { (due to pandemic) }\end{array}$ & $\begin{array}{l}\text { Customer segment } \\
\text { pivot }\end{array}$ \\
\hline Company-21 & $\begin{array}{l}\text { Customer feedback } \\
\text { (positive) }\end{array}$ & Zoom-in pivot \\
\hline Company-22 & $\begin{array}{l}\text { Market conditions } \\
\text { (due to pandemic) }\end{array}$ & $\begin{array}{l}\text { Complete pivot and } \\
\text { business architecture } \\
\text { pivot }\end{array}$ \\
\hline Company-23 & Competition & Zoom-in pivot \\
\hline Company-24 & Side project success & Side project pivot \\
\hline Company-25 & $\begin{array}{l}\text { Market conditions } \\
\text { (due to pandemic) }\end{array}$ & Platform pivot \\
\hline Company-26 & $\begin{array}{l}\text { Customer feedback } \\
\text { (negative) and flawed } \\
\text { business model }\end{array}$ & $\begin{array}{l}\text { Customer need pivot } \\
\text { and customer segment } \\
\text { pivot }\end{array}$ \\
\hline Company-27 & Side project success & Side project pivot \\
\hline Company-28 & $\begin{array}{l}\text { Market conditions } \\
\text { (due to pandemic) }\end{array}$ & Market segment pivot \\
\hline Company-29 & Unscalable business & Customer need pivot \\
\hline Company-30 & $\begin{array}{l}\text { Market conditions } \\
\text { (due to pandemic) }\end{array}$ & $\begin{array}{l}\text { Business architecture } \\
\text { pivot }\end{array}$ \\
\hline Company-31 & $\begin{array}{l}\text { Flawed business model, } \\
\text { technology challenges and } \\
\text { unscalable business }\end{array}$ & $\begin{array}{l}\text { Zoom-out pivot, } \\
\text { platform pivot, } \\
\text { customer segment } \\
\text { pivot, channel pivot } \\
\text { and business } \\
\text { architecture pivot }\end{array}$ \\
\hline
\end{tabular}




\begin{tabular}{|c|c|c|}
\hline Company & $\begin{array}{r}\text { Factor (s) } \\
\end{array}$ & Pivot (s) \\
\hline Company-32 & $\begin{array}{l}\text { Customer feedback } \\
\text { (positive) }\end{array}$ & Market segment pivot \\
\hline Company-33 & $\begin{array}{l}\text { Market conditions } \\
\text { (due to pandemic) }\end{array}$ & Customer need pivot \\
\hline Company-34 & $\begin{array}{l}\text { Customer feedback } \\
\text { (positive) }\end{array}$ & Zoom-in pivot \\
\hline Company-35 & $\begin{array}{l}\text { Customer feedback } \\
\text { (negative) }\end{array}$ & Customer need pivot \\
\hline Company-36 & $\begin{array}{l}\text { Market conditions } \\
\text { (due to pandemic) }\end{array}$ & Market segment pivot \\
\hline Company-37 & $\begin{array}{l}\text { Customer feedback } \\
\text { (negative) }\end{array}$ & $\begin{array}{l}\text { Customer segment } \\
\text { pivot }\end{array}$ \\
\hline Company-38 & $\begin{array}{l}\text { Market conditions } \\
\text { (due to pandemic) }\end{array}$ & Customer need pivot \\
\hline Company-39 & $\begin{array}{l}\text { Market conditions } \\
\text { (due to pandemic) }\end{array}$ & Side project pivot \\
\hline Company-40 & Side project success & Side project pivot \\
\hline Company-41 & $\begin{array}{l}\text { Influence of investor, } \\
\text { partner or founder, flawed } \\
\text { business model, market } \\
\text { conditions and technology } \\
\text { challenges }\end{array}$ & $\begin{array}{l}\text { Technology pivot, } \\
\text { channel pivot, engine } \\
\text { of growth pivot and } \\
\text { value capture pivot }\end{array}$ \\
\hline Company-42 & $\begin{array}{l}\text { Market conditions } \\
\text { (due to pandemic) }\end{array}$ & $\begin{array}{l}\text { Business architecture } \\
\text { pivot }\end{array}$ \\
\hline Company-43 & $\begin{array}{l}\text { Unscalable business and } \\
\text { technology challenges }\end{array}$ & $\begin{array}{l}\text { Zoom-in pivot, Zoom- } \\
\text { out pivot and } \\
\text { technology pivot }\end{array}$ \\
\hline Company-44 & $\begin{array}{l}\text { Unscalable business and } \\
\text { customer feedback } \\
\text { (positive) }\end{array}$ & $\begin{array}{l}\text { Complete pivot and } \\
\text { customer need pivot }\end{array}$ \\
\hline Company-45 & Technology challenges & Technology pivot \\
\hline Company-46 & Flawed business model & Customer need pivot \\
\hline Company-47 & Unscalable business & Complete pivot \\
\hline Company-48 & $\begin{array}{l}\text { Influence of investor, } \\
\text { partner or founder }\end{array}$ & Complete pivot \\
\hline Company-49 & $\begin{array}{l}\text { Influence of investor, } \\
\text { partner or founder and side } \\
\text { project success }\end{array}$ & Side project pivot \\
\hline Company-50 & $\begin{array}{l}\text { Influence of investor, } \\
\text { partner or founder }\end{array}$ & Customer need pivot \\
\hline Company-51 & $\begin{array}{l}\text { Market conditions } \\
\text { (due to pandemic) }\end{array}$ & Platform pivot \\
\hline Company-52 & $\begin{array}{l}\text { Customer feedback } \\
\text { (positive) and wrong } \\
\text { timing }\end{array}$ & Zoom-in pivot \\
\hline Company-53 & $\begin{array}{l}\text { Customer feedback } \\
\text { (negative), unscalable } \\
\text { business and competition }\end{array}$ & Complete pivot \\
\hline Company-54 & $\begin{array}{l}\text { Customer feedback } \\
\text { (negative) }\end{array}$ & Complete pivot \\
\hline Company-55 & $\begin{array}{l}\text { Customer feedback } \\
\text { (positive) }\end{array}$ & Zoom-in pivot \\
\hline Company-56 & Competition & Customer need pivot \\
\hline Company-57 & $\begin{array}{l}\text { Customer feedback } \\
\text { (negative) and influence of } \\
\text { investor, partner or founder }\end{array}$ & Channel pivot \\
\hline Company-58 & $\begin{array}{l}\text { Customer feedback } \\
\text { (negative) }\end{array}$ & Zoom-in pivot \\
\hline Company-59 & $\begin{array}{l}\text { Customer feedback } \\
\text { (positive) }\end{array}$ & $\begin{array}{l}\text { Customer segment } \\
\text { pivot }\end{array}$ \\
\hline Company-60 & $\begin{array}{l}\text { Influence of investor, } \\
\text { partner or founder, flawed } \\
\text { business model and } \\
\text { business financials }\end{array}$ & $\begin{array}{l}\text { Customer segment } \\
\text { pivot, value capture } \\
\text { pivot and engine of } \\
\text { growth pivot }\end{array}$ \\
\hline Company-61 & $\begin{array}{l}\text { Influence of investor, } \\
\text { partner or founder }\end{array}$ & Complete pivot \\
\hline Company-62 & Unscalable business & Platform pivot \\
\hline Company-63 & Technology challenges & Platform pivot \\
\hline
\end{tabular}

\begin{tabular}{|c|c|c|}
\hline Company & Factor (s) & Pivot (s) \\
\hline Company-64 & $\begin{array}{l}\text { Flawed business model, } \\
\text { business financials and } \\
\text { marker conditions }\end{array}$ & $\begin{array}{l}\text { Zoom-in pivot, Zoom- } \\
\text { out pivot, customer } \\
\text { segment pivot and } \\
\text { business architecture } \\
\text { pivot }\end{array}$ \\
\hline Company-65 & $\begin{array}{l}\text { Unscalable business and } \\
\text { customer feedback } \\
\text { (positive) }\end{array}$ & Customer need pivot \\
\hline Company-66 & $\begin{array}{l}\text { Influence of investors, } \\
\text { partners or founders }\end{array}$ & Side project pivot \\
\hline Company-67 & Unscalable business & Complete pivot \\
\hline Company-68 & Competition & Complete pivot \\
\hline Company-69 & Customer feedback & Customer need pivot \\
\hline Company-70 & $\begin{array}{l}\text { Customer feedback } \\
\text { (positive) }\end{array}$ & Zoom-in pivot \\
\hline Company-71 & $\begin{array}{l}\text { Market conditions } \\
\text { (due to pandemic) }\end{array}$ & Side project pivot \\
\hline Company-72 & Market conditions & Value capture pivot \\
\hline Company-73 & Technology challenges & $\begin{array}{l}\text { Technology pivot and } \\
\text { customer need pivot }\end{array}$ \\
\hline Company-74 & $\begin{array}{l}\text { Customer feedback } \\
\text { (positive) }\end{array}$ & Complete pivot \\
\hline Company-75 & Technology challenges & $\begin{array}{l}\text { Technology pivot and } \\
\text { customer need pivot }\end{array}$ \\
\hline Company-76 & $\begin{array}{l}\text { Customer feedback } \\
\text { (positive) }\end{array}$ & Customer need pivot \\
\hline Company-77 & $\begin{array}{l}\text { Market conditions } \\
\text { (due to pandemic) }\end{array}$ & Value capture pivot \\
\hline Company-78 & $\begin{array}{l}\text { Market conditions } \\
\text { (due to pandemic) }\end{array}$ & Platform pivot \\
\hline Company-79 & $\begin{array}{l}\text { Customer feedback } \\
\text { (negative) and wrong } \\
\text { timing }\end{array}$ & Customer need pivot \\
\hline Company-80 & Side project success & $\begin{array}{l}\text { Side project pivot and } \\
\text { customer segment } \\
\text { pivot }\end{array}$ \\
\hline
\end{tabular}

\section{RESULTS}

The objective behind studying the 80 technology startup companies through collecting secondary data was to secure a more in-depth understanding of pivoting and its associated factors. While analysing the secondary data, we calculated across the 80 companies the number of times (and percentage) a pivot was pursued and number of times a factor triggered pivoting, which is provided in Table IV and $\mathrm{V}$ respectively. The bar charts (Fig. 1 and 2) are graphical representations of these tables. For example, the factor customer feedback was a driver for selecting a pivot by twenty-seven different startups. Of these twenty-seven startups, seven of them used zoom-in pivot; four startups pursued customer segment pivot; eight startups pursued customer need pivot; five startups pursued complete pivot while three startups pursued platform pivot, channel pivot or a market segment pivot.

TABLE IV. FREQUENCY OF PIVOTS PURSUED BY THE TECH STARTUPS

\begin{tabular}{|l|l|l|}
\hline \multicolumn{1}{|c|}{ Type of pivots } & No. of times pursued & Percentage \\
\hline Social pivot & 0 & $0 \%$ \\
\hline Market segment pivot & 2 & $1 \%$ \\
\hline Complete pivot & 8 & $4 \%$ \\
\hline Technology pivot & 9 & $5 \%$ \\
\hline
\end{tabular}




\begin{tabular}{|l|l|l|}
\hline \multicolumn{1}{|c|}{ Type of pivots } & No. of times pursued & Percentage \\
\hline Zoom-out pivot & 10 & $5 \%$ \\
\hline Platform pivot & 11 & $6 \%$ \\
\hline Zoom-in pivot & 13 & $7 \%$ \\
\hline Channel pivot & 14 & $7 \%$ \\
\hline Business architecture pivot & 14 & $7 \%$ \\
\hline Engine of growth pivot & 17 & $9 \%$ \\
\hline Side project pivot & 17 & $9 \%$ \\
\hline Value capture pivot & 21 & $11 \%$ \\
\hline Customer need pivot & 23 & $12 \%$ \\
\hline Customer segment pivot & 28 & $15 \%$ \\
\hline Grand Total & $\mathbf{1 8 7}$ & $\mathbf{1 0 0} \%$ \\
\hline
\end{tabular}

The bar chart in Fig. 1 represents the frequency of each pivot pursued by a tech startup. For instance, customer segment pivot was the highest pursued pivot $(\mathrm{N}=28,15 \%)$. Customer need pivot is the second most pursued pivot among the 80 startup companies $(\mathrm{N}=23,12 \%)$ followed by value capture pivot $(\mathrm{N}=21,11 \%)$. Market segment pivot is the least pursued pivot $(\mathrm{N}=2,1 \%)$. We could not identify a single tech startup that pursued social pivots in order to validate.

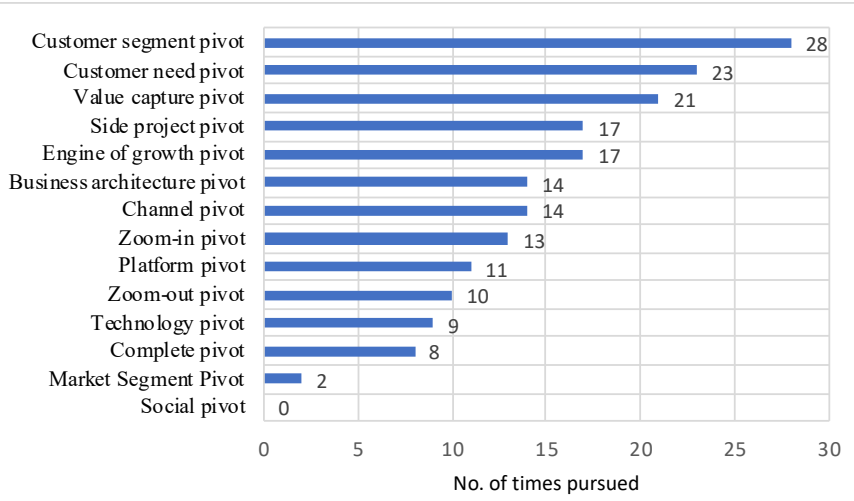

Fig. 1. Frequency of pivots pursued by the tech startups

TABLE V. FREQUENCY OF FACTORS THAT TRIGGERED PIVOTS

\begin{tabular}{|l|l|l|}
\hline \multicolumn{1}{|c|}{ Factors } & No. of times occurred & Percentage \\
\hline Legal issues & 1 & $1 \%$ \\
\hline Wrong timing & 3 & $2 \%$ \\
\hline Competition & 4 & $2 \%$ \\
\hline Side project success & 5 & $3 \%$ \\
\hline Business financials & 15 & $8 \%$ \\
\hline Market conditions & 17 & $9 \%$ \\
\hline MC-Pandemic & 19 & $10 \%$ \\
\hline Unscalable business & 20 & $11 \%$ \\
\hline $\begin{array}{l}\text { Influence of investor, } \\
\text { partner or founder }\end{array}$ & 22 & $12 \%$ \\
\hline
\end{tabular}

\begin{tabular}{|l|l|l|}
\hline \multicolumn{1}{|c|}{ Factors } & No. of times occurred & Percentage \\
\hline Technology challenges & 24 & $13 \%$ \\
\hline Customer feedback & 27 & $14 \%$ \\
\hline Flawed business model & 30 & $16 \%$ \\
\hline Grand Total & $\mathbf{1 8 7}$ & $\mathbf{1 0 0 \%}$ \\
\hline
\end{tabular}

Fig. 2 illustrates the frequency of each factor that has triggered a tech startup company to pivot. For example, the bar chart shows that the flawed business model was the most triggered factor $(\mathrm{N}=30,16 \%)$, followed by customer feedback $(\mathrm{N}=27,14 \%)$ and technology challenges $(\mathrm{N}=24,13 \%)$. Whereas competition $(\mathrm{N}=4,2 \%)$, wrong timing $(\mathrm{N}=3,2 \%)$ and legal issues $(\mathrm{N}=1,1 \%)$ are the least triggered factors. Therefore, the customer segment, customer need, and value capture pivots are the most pursued pivots. Similarly, the flawed business model, customer feedback and technology challenges are the most triggering factors.

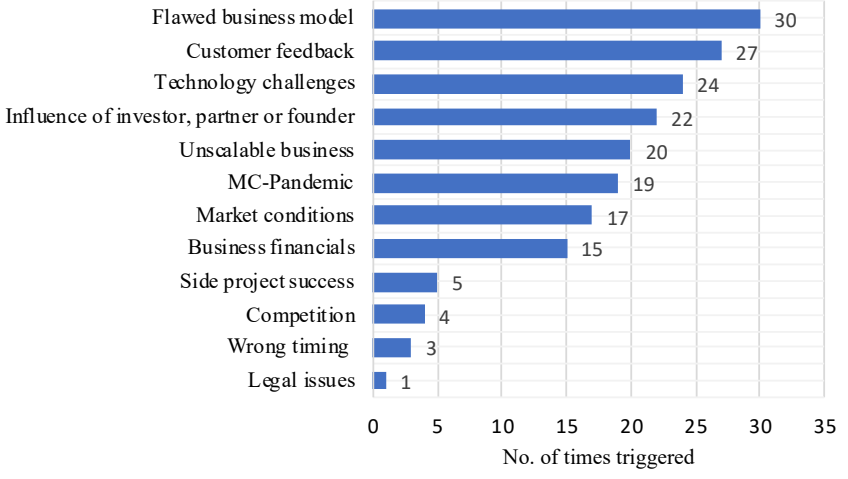

Fig. 2. Frequency of each factor that triggered the pivot

\section{CONCLUSION}

This exploratory research study focuses on understanding the concept of technology entrepreneurship through examining the lean startup approach, pivots and the factors that trigger such pivots. Technology entrepreneurship is a critical field that can enhance economic growth and create new technologydriven market opportunities [3]. Therefore, the question arises: How can a technology startup company survive in the long run? One way to address the question is by implementing LSA. As the Lean Startup approach (LSA) encourages startups to interact with customers and promotes them to test new fundamental hypotheses to improve the product/service based on the feedback [35]. From the secondary data analysis, we observed that the most frequently pursued pivots are customeroriented types of pivots i.e., customer segment pivot (15\%) and customer need pivot $(12 \%)$ followed by the value capture pivot $(11 \%)$. However, we could not identify any examples for the social pivot which was proposed by Hirvikoski [12].

Pivoting is defined as changing the course of direction by a tech startup. Product, market, strategy and people level pivots are the four categories out of which a startup can opt a single pivot or multiple pivots to test their new hypothesis. However, 
the following aspects are yet to be explored: How many times a tech startup has to pivot to identify a market fit product? Does a pivot lead to another pivot (i.e., a domino effect)? Whether there is a correlation between pivots and the factors? Therefore, future research should focus on collecting primary data to identify new pivots and factors, determine the domino effect, and the influence of pivoting on the value proposition.

\section{ACKNOWLEDGMENT}

This research study is funded by The Puri Foundation and their support is gratefully acknowledged.

\section{REFERENCES}

[1] D. Shepherd and M. Gruber, "The Lean Startup Framework: Closing the Academic-Practitioner Divide", Entrepreneurship Theory and Practice, p. $104225871989941,2020$.

[2] M. Spiegel and C. Marxt, "Defining Technology Entrepreneurship", in Proc. IEEE International Conference on Industrial Engineering and Engineering Management, 2011.

[3] S. Eliakis, D. Kotsopoulos, A. Karagiannaki and K. Pramatari, "Survival and Growth in Innovative Technology Entrepreneurship: A MixedMethods Investigation", Administrative Sciences, vol. 10, no. 3, p. 39, 2020.

[4] M. Low and I. MacMillan, "Entrepreneurship: Past Research and Future Challenges", Journal of Management, vol. 14, no. 2, pp. 139-161, 1988.

[5] D. Frederiksen and A. Brem, "How do entrepreneurs think they create value? A scientific reflection of Eric Ries' Lean Startup approach", International Entrepreneurship and Management Journal, vol. 13, no. 1, pp. 169-189, 2017.

[6] R. Amit, L. Glosten and E. Muller, "Challenges to theory development in entrepreneurship research*”, Journal of Management Studies, vol. 30, no. 5, pp. 815-834, 1993.

[7] D. Urbano, M. Guerrero, J. Ferreira and C. Fernandes, "New technology entrepreneurship initiatives: Which strategic orientations and environmental conditions matter in the new socio-economic landscape?", The Journal of Technology Transfer, vol. 44, no. 5, pp. 1577-1602, 2019.

[8] R. Sobel and J. Clark, "The use of knowledge in technology entrepreneurship: A theoretical foundation", The Review of Austrian Economics, vol. 31, no. 2, pp. 195-207, 2018.

[9] J. Rakicevic, M. Levi Jaksic and M. Jovanovic, "Measuring the Potential for Technology Entrepreneurship Development: Serbian Case", Management:Journal of Sustainable Business and Management Solutions in Emerging Economies, vol. 23, no. 2, p. 13, 2018.

[10] T. Ratinho, R. Harms and S. Walsh, "Structuring the Technology Entrepreneurship publication landscape: Making sense out of chaos", Technological Forecasting and Social Change, vol. 100, pp. 168$175,2015$.

[11] A. Ghezzi and A. Cavallo, "Agile Business Model Innovation in Digital Entrepreneurship: Lean Startup Approaches", Journal of Business Research, vol. 110, pp. 519-537, 2020.

[12] K. Hirvikoski, "Startups Pivoting Towards Value", Data-and ValueDriven Software Engineering with Deep Customer Insight, vol. 1, 2014.

[13] E. Ries, The Lean Startup: How Today's Entrepreneurs use Continuous Innovation to Create Radically Successful Businesses. Crown Books, 2011.

[14] J. McMullen, "Are you pivoting away your passion? The hidden danger of assuming customer sovereignty in entrepreneurial value creation", Business Horizons, vol. 60, no. 4, pp. 427-430, 2017.

[15] R. Harms and M. Schwery, "Lean Startup: Operationalizing Lean Startup Capability and testing its performance implications", Journal of Small Business Management, vol. 58, no. 1, pp. 200-223, 2020.

[16] S. S. Bajwa, X. Wang, A. N. Duc and P. Abrahamsson, "Failures to be celebrated: an analysis of major pivots of software startups", Empirical Software Engineering, vol. 22, no. 5, pp. 2373, 2017.
[17] F. S. Martins, da Cunha, Júlio Araujo Carneiro and F. A. R. Serra, "Secondary data in research-uses and opportunities", PODIUM Sport, Leisure and Tourism Review, vol. 7, no. 3, 2018.

[18] Q. Trinh, "Understanding the impact and challenges of secondary data analysis", Urologic Oncology: Seminars and Original Investigations, Vol. 36, no. 4, pp. 163-164, 2018.

[19] C. Comberg, S. Friedemann, A. German and V. K. Velamuri, "Pivots in startups: Factors influencing business model innovation in startups", in Proc. The International Society for Professional Innovation Management, p. 1, 2014.

[20] H. Terho, S. S Suonsyrjä, A. Karisalo and T. Mikkonen, "Ways to cross the rubicon: Pivoting in software startups", in Proc. International Conference on Product-Focused Software Process Improvement, pp. 555-568, 2015.

[21] I. Woodford. "These 19 European startups have pivoted in the face of coronavirus." Shifted.eu. https://sifted.eu/articles/coronavirus-pivotstartups/ (accessed Mar. 21, 2021).

[22] University of Oxford. "OXFO Ventures responding to COVID-19." OXFO. https://www.oxfordfoundry.ox.ac.uk/oxfo-ventures-respondingcovid-19 (accessed Mar. 21, 2021).

[23] A. Langevin. "22 businesses pivoting through COVID-19." Maddyness. https://www.maddyness.com/uk/2020/06/09/22-businesses-pivotingthrough-covid-19/ (accessed Mar. 21, 2021).

[24] N. Arora. "COVID-19: 7 Brands that have pivoted." ChannelSight. https://www.channelsight.com/blog/covid-19-brands-that-pivoted (accessed Mar. 21, 2021).

[25] J. Nazar. "14 Famous business pivots." Forbes. https://www.forbes.com/sites/jasonnazar/2013/10/08/14-famousbusiness-pivots/?sh=6739801b5797 (accessed Mar. 21, 2021).

[26] J. Pruitt. "4 Companies and how they successfully pivoted." Inc. https://www.inc.com/jeff-pruitt/4-companies-and-how-theysuccessfully-pivoted.html (accessed Mar. 21, 2021).

[27] R. Hinchliffe "Moven shuts all consumer accounts, pivots to B2B-only service for banks." Fintech Futures. https://www.fintechfutures.com/2020/03/moven-shuts-allconsumer-accounts-pivots-to-b2b-only-service-for-banks/ (accessed Mar. 21, 2021).

[28] S. Glaveski. "The top 10 company pivots of all-time." Collective Campus. https://www.collectivecampus.io/blog/the-top-10-company-pivots-ofall-time (accessed Mar. 21, 2021).

[29] M. Gebel. "9 of the biggest pivots in tech history, from Nintendo to Instagram." Insider. https://www.businessinsider.com/tech-companybiggest-pivots-nintendo-instagram-amazon-2019-8? $\mathrm{r}=\mathrm{US} \& \mathrm{IR}=\mathrm{T}$ (accessed Mar. 21, 2021).

[30] K. O’Sullivan. "Most successful business pivots in history." Superscript. https://gosuperscript.com/blog/most-successful-business-pivots-inhistory/ (accessed Mar. 21, 2021).

[31] H. Ringle. "Tallwave triples employees and offers digital marketing with new acquisition.", Phoenix Busniess Journal. https://www.bizjournals.com/phoenix/news/2017/03/31/tallwave-triplesemployees-and-offers-digital.html (accessed Mar. 21, 2021).

[32] B. Morgan. "10 examples of how covid-19 forced business transformation." Forbes. https://www.forbes.com/sites/blakemorgan/2020/05/01/10-examples-ofhow-covid-19-forced-business-transformation/?sh=7d4478b31be3 (accessed Mar. 21, 2021).

[33] H. Zhang. "360 Pivot: How covid-19 disrupted then propelled yhangry." Startups Magazine. https://startupsmagazine.co.uk/article-360-pivothow-covid-19-disrupted-then-propelled-yhangry (accessed Mar. 21, 2021).

[34] P. Whitney. "How 5 companies used Covid to pivot to success." Hallidays. https://www.hallidays.co.uk/views-and-insight/blog/how-5companies-used-covid-to-pivot-to-success (accessed Mar. 21, 2021).

[35] T. Felin, A. Gambardella, S. Stern and T. Zenger, "Lean startup and the business model: Experimentation revisited", Long Range Planning, vol. 53, no. 4, p. 101953, 2020. 